\title{
Erratum to: Glomerulopathy in patients with distal duplication of chromosome $6 p$
}

\author{
Augustina Jankauskienè ${ }^{1 *}$, Magdalena Koczkowska², Anna Bjerre ${ }^{3}$, Joanna Bernaciak ${ }^{4}$, Franz Schaefer ${ }^{5}$
}

and Beata S. Lipska-Ziętkiewicz ${ }^{2}$

\section{Erratum}

Following publication of the original article in $B M C$ Nephrology [1], we would like to alert the reader that the displayed grant number $(011 / 01 / \mathrm{D} / \mathrm{NZ2} / 01600)$ is incorrect and should read as 2011/01/D/NZ2/01600.

The original article has been updated with the correct grant number. The publisher apologizes for the inconvenience this may have caused.

\footnotetext{
Author details

'Vilnius University, Children hospital affiliate of Vilnius university hospital "Santariskiu klinikos", Santariskiu 4, Vilnius, LT 08406, Lithuania. Department of Biology and Genetics, Medical University of Gdańsk, Dębinki 1, Gdańsk 80211, Poland. ${ }^{3}$ Department of Pediatrics, Oslo University Hospital, Oslo, Norway. ${ }^{4}$ Department of Medical Genetics, Institute of Mother and Child, Warsaw, Poland. ${ }^{5}$ Division of Pediatric Nephrology, Center for Pediatrics and Adolescent Medicine, Heidelberg, Germany.
}

Received: 22 March 2016 Accepted: 14 April 2016

Published online: 26 April 2016

\section{Reference}

1. Jankauskiene A et al. Glomerulopathy in patients with distal duplication of chromosome 6p. BMC Nephrol. 2016;17:32.

* Correspondence: augustinajankauskiene@yahoo.com

${ }^{1}$ Vilnius University, Children hospital affiliate of Vilnius university hospital

"Santariskiu klinikos", Santariskiu 4, Vilnius, LT 08406, Lithuania
Submit your next manuscript to BioMed Central and we will help you at every step:

- We accept pre-submission inquiries

- Our selector tool helps you to find the most relevant journal

- We provide round the clock customer support

- Convenient online submission

- Thorough peer review

- Inclusion in PubMed and all major indexing services

- Maximum visibility for your research

Submit your manuscript at

www.biomedcentral.com/submit

\section{() Biomed Central}

